\title{
マイクロ $\mathrm{Ni}-\mathrm{W}$ 電着ダイヤモンドエ具の製作と シリコンの溝加エへの適用*
}

\author{
鬼鞍宏猷** 大西 修** 西原邦男 ${ }^{* * *}$ 坂瀬忠之十 \\ 森 勇樹 ${ }^{+t}$ 朴 興吉 ${ }^{+t+}$ 郭 韋辰 ${ }^{+t+}$ 藤井祐紀 ${ }^{+t+}$
}

Fabrication of Micro Ni-W Electroplated Diamond Tools and Their Application to Grooving of Silicon

Hiromichi ONIKURA, Osamu OHNISHI, Kunio NISHIHARA, Tadayuki SAKASE, Yuki MORI, Heungkil PARK, Weichen KUO and Yuki FUJII

\begin{abstract}
The present paper deals with a fabrication method of micro Ni-W electroplated diamond tools with a diameter of $100 \mu \mathrm{m}$ and their machining characteristics in grooving into silicon, in order to estimate the machining performance of the tools and optimize the fabrication conditions. In fabricating $2-4 \mu \mathrm{m}$ diameter grit tools, more uniform distribution of grits was obtained through the solution stirring by jet, which resulted in a reduction in tool life scatter. The optimal electric current density was obtained regarding tool condition and tool life. Cutting speed and feed rate were optimized from the viewpoint of tool life.
\end{abstract}

Key words: Ni-W electroplating, diamond, micro tool, silicon, grooving, machining accuracy, tool life

\section{1. 緒言}

情報通信機器, 医療機器, 化学反応装置および各種セン サなどの高集積化・高性能化が進む中で, 延性材料（軽合 金，ステンレス鋼，チタン合金）および脆性材料（シリコ ン, ガラス, 超硬合金, セラミックス) などの $\mu \mathrm{m}$ レベルの 寸法要素からなる 2 次元 $/ 3$ 次元金型・部品の製作が必要 とされている.これらの製作に機械的マイクロ加工を適用 することは, 能率, 精度, コストなどの総合的な面からメ リットがある. その工具としては, 超硬合金切削工具 ${ }^{1)}$, 単 結晶ダイヤモンド切削工具 ${ }^{2}$, 研削工具（ダイヤモンド／ $\mathrm{CBN}$ メタルボンド工具 ${ }^{3)}$, ダイヤモンド $/ \mathrm{CBN}$ 電着・電鋳

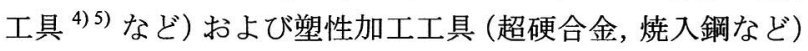
があるが, 延性材料や脆性材料の加工, および高アスペク ト比の加工に広く使用できるのは, ダイヤモンド切削・研 削工具である，中でも，超硬合金台金のダイヤモンド電着 工具は工具剛性と耐摩耗性が高いので高精度加工が可能で あり，低コストである。

本研究の目的は, 高精度 ・高能率の加工が可能で, 耐久 性が高い高剛性の超硬合金台金円筒状 Ni-W 電着マイクロ ダイヤモンド工具の信頼性の高い製作技術と適用方法の開 発である. 具体的には, まず $\mathrm{Ni}-\mathrm{W}$ 電着工具と $\mathrm{Ni}$ 電着工具 の基礎的特性を比較した後, $\mathrm{Ni}-\mathrm{W}$ 電着工具の再現性の高い 製作方法を提案するとともに，種々の製作条件（台金の洗 浄方法. 液の擋汼方法, $\mathrm{pH}$, 温度, 電流密度, 電着時間,

* 原稿受付 平成 18 年 6 月 4 日

** 正 会 員 九州大学大学院（福岡市西区元岡 744）

*** 正会 員 九州職業能力開発大学校 (北九州市小倉南区志 井 1665-1)

† 九州大学大学院 (現, オムロン(株) ; 滋賀県草津市西草津 2-2-1)

† 九州大学大学院 (現, ヤマザキマザック(株); 愛知県丹羽郡 大口町乗船 1)

t†学生会員 九州大学大学院（福岡市西区元岡 744）

†t十 九州大学 (現, 第一精工(株) ; 福岡県小郡市三沢 863)
埋込み時間など）で工具を製作する.その後，製作した工 具を用い加工条件を変えて単結晶シリコンに溝加工を行い, 寿命と精度から見て最適な製作・適用条件を見出す。

\section{2. 実験装置および方法}

\section{1 マイクロ電着エ具の製作}

電着工具の製作工程は（1）台金の洗浄，（2）ダイヤモ ンド砥粒の電着, および（3）埋込みめっき, からなる. 台金の洗浄は, 表 1 に示すように, (1)アセトン中での超音 波洗浄, (2)陰極電解脱脂, (3)酸浸漬, の3 段階からなり,

Table 1 Cleaning conditions

\begin{tabular}{l|l}
\hline (1) & Ultrasonic cleaning in acetone \\
\hline$(2)$ & $\begin{array}{l}\text { Electrolytic degreasing at } 60^{\circ} \mathrm{C} \text { and } 8.5 \mathrm{~A} / \mathrm{dm}^{2} \text { and } \\
\text { for } 5 \mathrm{~min}\end{array}$ \\
\hline$(3)$ & Soaking in sulfuric acid diluted by 20 times \\
\hline
\end{tabular}

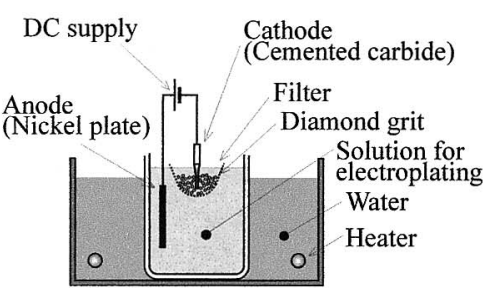

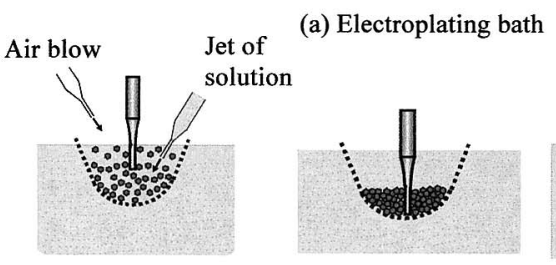

(b) Stirring method for $2-4 \mu \mathrm{m}$ dia. grits

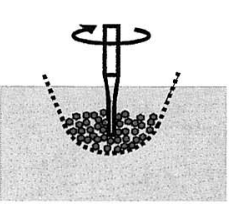

(c) Stationary soaking

(d) Rotational soaking for $5-10 \mu \mathrm{m}$ and 8-16 $\mu \mathrm{m}$ dia. grits
Fig. 1 Electroplating method 
Table 2 Electroplating conditions

\begin{tabular}{l|l|l}
\hline Parameter & Ni electroplating & Ni-W electroplating \\
\hline Bath & Watts bath & Ammonia citrate bath \\
& $\mathrm{NiSO}_{4}, \mathrm{NiCl}_{2}$, & $\begin{array}{c}\mathrm{Ni}\left(\mathrm{SO}_{3}\right)_{2} \cdot 4 \mathrm{H}_{2} \mathrm{O}, \\
\left(\mathrm{NH}_{4}\right)_{10} \mathrm{~W}_{12} \mathrm{O}_{41} \cdot 5 \mathrm{H}_{2} \mathrm{O}, \\
\end{array}$ \\
& $\mathrm{H}_{3} \mathrm{BO}_{3}$ & $\mathrm{C}_{6} \mathrm{H}_{5} \mathrm{O}_{7}(\mathrm{COOH})_{3}$ \\
\hline Current density & $2 \mathrm{~A} / \mathrm{dm}^{2}$ & $0.5,1,2,4,6 \mathrm{~A} / \mathrm{dm}^{2}$ \\
\hline Temperature & $60^{\circ} \mathrm{C}$ & $60^{\circ} \mathrm{C}$ \\
\hline Time & $2-5 \mathrm{~min}$ & $7.5-60 \mathrm{~min}$ \\
\hline
\end{tabular}

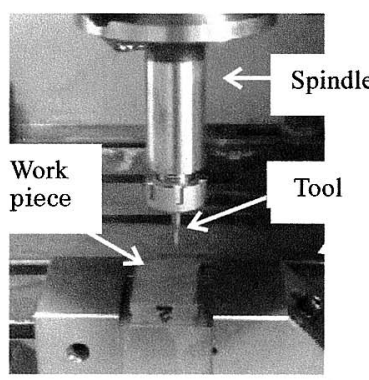

Fig. 2 Situation of grooving with BT shank

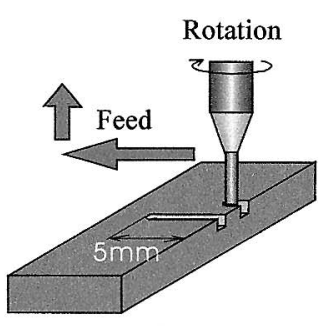

Fig. 3 Schematic diagram of grooving
洗浄の合間に水洗を行う。電着は，図 1 (a)に示すように, 一定温度に保持した水槽に電着液を入れたビーカを置き電 着液中に $\mathrm{Ni}$ 板（陽極）と超硬棒（陰極）を入れて行う。ダ イヤモンド砥粒はフィルタで保持する. $\mathrm{Ni}$ 電着はワット浴 で, Ni-W 電着はアンモニア性クエン酸塩浴で行う. 電着条 件を表 2 に示す，台金は超々微粒超硬合金で，電着部分は 直径 $100 \mu \mathrm{m}$, 長さ $500 \mu \mathrm{m}$ の円筒状である. ダイヤモンド粒

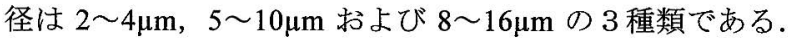

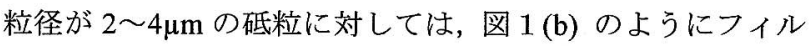
夕内で手動または自動により閒欠的に液の噴流を送り砥粒 を巻き上げるとともに空気を水面に吹きかけて液を流動さ せる方法と，台金を沈積したダイヤモンド砥粒中に挿入し て電着を行う方法を用いる（図 1 (c)). 粒径が 5 10 $\mu$ m と

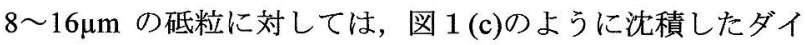
ヤモンド砥粒中に台金を挿入して電着を行う方法と, 図 1 (d)のようにダイヤモンド砥粒中に台金を挿入して台金を回 転させながら電着を行ら方法を用いる。

\section{2 製作した電着工具を用いた加エ}

単結晶シリコンを工作物とし，製作した電着工具の性能 を評価するために, CNC 立型研削盤の主軸（ $Z$ 軸）に取付 けて溝削りを行った. 工具は BTシャンクを介して主軸に直 接，または高速主軸に取付けてそれを機械主軸に保持した

(図 2 参照)。加工実験は，図３に示すように溝深さを $100 \mu \mathrm{m}, 1$ 本の溝長を $5 \mathrm{~mm}$ とし, 工具が折損するまで溝を 多数本加工した。油剤は水溶性研削油を供給した. 電着工 具の回転速度は $5,000 \sim 50,000 \mathrm{~min}^{-1}$, 送り速度は 50 〜 $3,600 \mu \mathrm{m} / \mathrm{min}$ とした.

\section{3. 実験結果および考察}

本研究で開発する電着工具は，以下の特色を有する.

(a) 鋼に比べ剛性の高い超硬合金を台金とすること

(b) 台金直径が約 $100 \mu \mathrm{m}$ の極小径であること

(c) Ni 電着より硬く, 砥粒保持力が高く, しかも W を 含む台金の超硬合金との親和性が高いと思われる
Table 3 Comparison of Young's modulus $E$ and Vicker's Hardness HV of various tools

\begin{tabular}{|c|c|c|}
\hline Properties & $\begin{array}{l}\text { Young's } \\
\text { modulus } \\
E \quad \mathrm{GPa}\end{array}$ & $\begin{array}{c}\text { Vicker's } \\
\text { Hardness } \\
\text { HV }\end{array}$ \\
\hline $\begin{array}{l}\mathrm{Ni} \text { electroplated tool } \\
\text { with carbide substrate }\end{array}$ & approx. $600^{*}$ & $200^{* * *}$ \\
\hline $\begin{array}{l}\mathrm{Ni}-\mathrm{W} \text { electroplated tool } \\
\text { with carbide substrate }\end{array}$ & approx. $600^{*}$ & $620 * * *$ \\
\hline Ni electroformed tool & approx. $206 * *$ & $200 * * * *$ \\
\hline $\mathrm{Ni}-\mathrm{W}$ electroformed tool & - & $620 * * * *$ \\
\hline
\end{tabular}

$\mathrm{Ni}-\mathrm{W}$ 電着を対象とすること

(d) 台金上の砥粒分布の一様化を試みること

\subsection{Ni/Ni-W 電着工具と $\mathrm{Ni} / \mathrm{Ni}-\mathrm{W}$ 電鋳工具の基礎的特性}

\subsection{1 電着 /電鋳工具の縦弾性係数と硬さ}

電着工具の基材として, 曲げ岡性を考慮して縦弾性係数 $E$ が焼入鋼 (206GPa) の約 3 倍である超硬合金を採用した（表

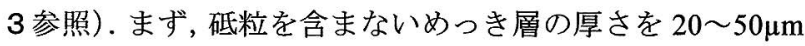
にして硬さ試験を行ったところ，表 3 に示すように平均値 でNi めっきはHV200, Ni-W めっきはHV620 となった.す なわち，Ni-W は Ni の約 3 倍の硬さを有することがわかっ た．以上より，工具剛性とめっき層硬さに関して，超硬台 金 Ni-W 電着工具の他の工具に対する優位性が示された.

\section{1 .2 めっき膜と台金の密着性}

めつき層と超硬台金との密着の程度を調べるために，厚

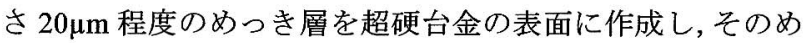
っき面を最大 $3 \mathrm{~N}$ の荷重を加えたビッカースの圧子で引掻 いた. その結果, Ni めっき, Ni-W めっきともに膜の剥離は 起こらず，超硬台金との密着性は良好であることがわかっ た.ここで，めっき面は表 1 の洗浄工程を経たものである.

\section{$3.2 \mathrm{Ni}$ 電着工具および $\mathrm{Ni}-\mathrm{W}$ 電着工具を用いた単結晶シ リコンの溝加工予備実験}

まず粒径 2〜 $4 \mu \mathrm{m}$ のダイヤモンド砥粒を用いて, 電流密度 $2,4 \mathrm{~A} / \mathrm{dm}^{2}$, 電着液無摚拌の条件下で, $\mathrm{Ni}$ 電着工具をワット 浴, Ni-W 電着工具をアンモニア性クェン酸塩浴で製作した。 これらの電着工具を用いて, 単結晶シリコンの溝加工（深 さ $200 \mu \mathrm{m})$ を行い工具寿命と加工溝の精度を比較した. 工 具が折損するまでの加工溝長さを工具寿命と定義し，電流 密度（電着時間は電流密度と反比例するように設定）を変 えた工具を用いて送り $50 \mu \mathrm{m} / \mathrm{min}$ で溝加工し寿命を調べた ところ, 電着条件の違いによる寿命の差は小さく, Ni 電着 工具は 4.1〜 $5.0 \mathrm{~mm}, \mathrm{Ni}-\mathrm{W}$ 電着工具は 8.3〜 10.7mm となった. すなわち $\mathrm{Ni}-\mathrm{W}$ 電着工具は $\mathrm{Ni}$ 電着工具の約 2 倍の工具寿命 となることがわかった. 工具寿命の差は, Ni-W 電着層が $\mathrm{Ni}$ 電着層より硬いため切りくずなどに対する耐摩耗性が高 いことが理由の一つである．また，台金との密着性や砥粒 保持力が優っている可能性があることも理由の一つと推定 される.また 2 種類の工具ともに, 加工初期の溝入口にチ ッピングは見られず，コーナ部も比較的シャープな角を呈 し, 溝の側面や底面の粗さも小さく, 両者にほとんど差は ない.この結果に基づいて, 以後, $\mathrm{Ni}-\mathrm{W}$ 電着工具の製作お よび加工を行うこととする. 


\subsection{Ni-W 電着工具の製作条件}

\subsection{1 台金の洗浄}

台金と電着膜との密着性を高めるために，台金の表面か ら発生する水素ガスなどを利用する電解脱脂を行ったとこ ろ，台金表面の微小なクラックにおいても十分な洗浄が行 われ, 剥離は起こらなくなった. 条件は電流密度 $8.44 \mathrm{~A} / \mathrm{dm}^{2}$, 時間 $5 \mathrm{~min}$ である.

\subsection{2 電着液の摚找方法が電着工具表面の砥粒分布に及 ぼす影響}

砥粒径 2 4 $4 \mu \mathrm{m}$ の場合, 当初は台金をフィルタ内の砥粒に 沈漬する（図 1 (c)）方法で電着を試みていたが，台金表面上の 砥粒分布が一様にならなかった（図 $4(\mathrm{a})$ )。このときの砥粒 分布密度を電着工具表面の $20 \mu \mathrm{m} \times 20 \mu \mathrm{m}$ の領域の異なる箇 所について調べたところ，7,500～190,000 個 $/ \mathrm{mm}^{2}$ 範囲でば らついていることが明らかになった，そこで，図 1 (b) のよ うに，台金を砥粒に漬からない程度に引上げ，電着液の噴 流を沈積した砥粒に手動により適当な時閒間隔で間欠的に 吹きかけて砥粒を巻上げ，液表面に空気を吹きかけ液を流 動させる形で擋拌を行った。その結果，擋拌により砥粒分 布はかなり向上した (一例が図 4(b)).ここで液の噴流を送 る方法を，ポンプから自動的に一定の時間閒隔で噴流を送 る方法にしたところ，図4(c)のように手動擋汼とほぼ同等 の一様な砥粒分布が得られた。これらの工具表面における 砥粒密度は，図 5 に示すように，手動擋拌，自動擋拌いず れの場合も $37,500 \sim 100,000$ 個 $/ \mathrm{mm}^{2}$ となり，無擋汼の場合 に比べ砥粒分布密度が狭い範囲に収まることが明らかにな った.

\subsection{3 台金の回転が電着工具表面の砥粒分布に及ぼす影} 響

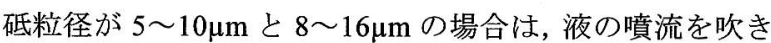
かけても砥粒が早く沈降し，台金への電着がうまく行えな かったため，図1(c)の方法（前述）で行った。しかし，台 金を電着液中の砥粒層の中に挿入する際，台金が軸直角方

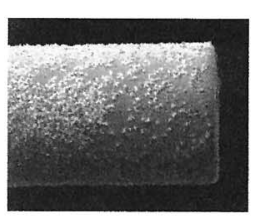

(a) no stirring

(c) automatic stirring Grit diameter $2-4 \mu \mathrm{m}$

Fig. 4 Tools fabricated under different current densities

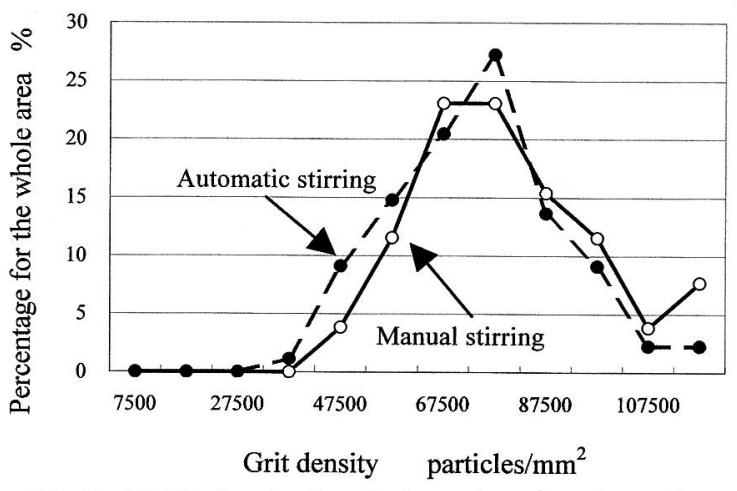

Fig. 5 Distribution density of grits on the tool surface without and with stirring
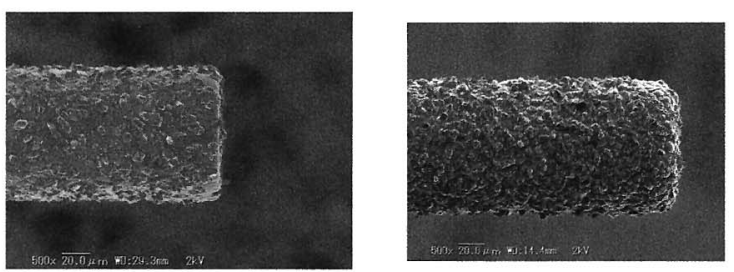

$\longmapsto 100 \mu \mathrm{m} \quad 5 \mathrm{~min}^{-1}$

(a) In case of stationary substrate (b) In case of rotating substrate Substrate diameter $80 \mu \mathrm{m}$, Grit diameter $5-10 \mu \mathrm{m}$, Elec. time $20 \mathrm{~min}$, Embed. time $8 \mathrm{~min}$

Fig. 6 Effect of substrate rotation on grit distribution $-10 \mu \mathrm{m}$

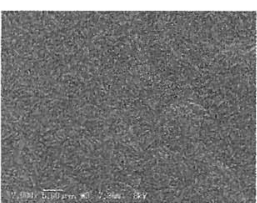

(a) $0.5 \mathrm{~A} / \mathrm{dm}^{2}$

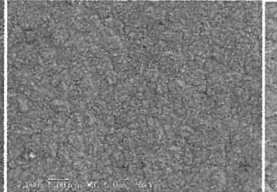

(b) $1 \mathrm{~A} / \mathrm{dm}^{2}$

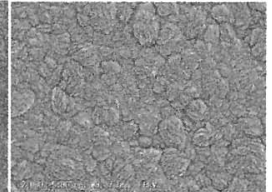

(c) $2 \mathrm{~A} / \mathrm{dm}^{2}$
With automatic stirring, Grit diameter $2-4 \mu \mathrm{m}$

Fig. 7 Electroplated surfaces with different current densities

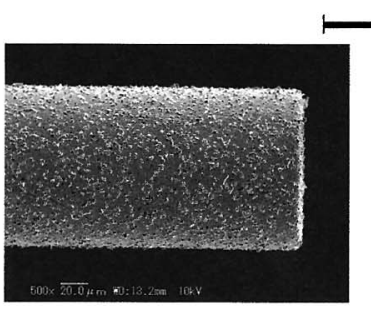

(a) $1 \mathrm{~A} / \mathrm{dm}^{2}$

$30 \mathrm{~min}$
Fig. 8 Tools fabricated under different current densities

向にわずかに動くため，台金から離れた砥粒層が生じる. この部分では台金に砥粒が付きにくく砥粒分布が不均一と なることがあった，そこで，台金を $5 \mathrm{~min}^{-1}$ で回転させなが らロータリコネクタを通して電流を流して電着を行い，工 具表面上の砥粒分布を非回転の場合と比較した．図 6 に示 すように，非回転工具に比べ回転工具の表面の砥粒密度の ばらつきが少ないことがわかる．ただ，工具コーナ部に大 きな丸みを帯びる結果となった.

3.3.4 電流密度と電着時間が電着工具状態に及ぼす影響 まず $0.5 \sim 2 \mathrm{~A} / \mathrm{dm}^{2}$ の範囲で電流密度を变えてめっき膜の 状態を観察した。図7に示すように, 電流密度が高いほど 膜面の「きめ」が粗くなり空孔も見られることがあること が明らかになった. 次に砥粒を含めて電着を行うと, $2 \mathrm{~A} / \mathrm{dm}^{2}$ までは膜面状態と砥粒の保持は良好であるが（図 8 (a)）, $4 \mathrm{~A} / \mathrm{dm}^{2}$ 以上では（1）めっき膜, 電着膜の剥離やクラック が起こり易いこと（図 8(b)), および（2）工具コーナの丸 みがやや増加する傾向があること，などの事実が明らかに なった，そこで，電着時間も考慮して，以後 $1 \sim 2 \mathrm{~A} / \mathrm{dm}^{2}$ で 電着を行うこととした.ここで，（1）の原因は膜内の引張 残留応力によるものであり（2）の原因はコーナ部に集中 する電流束によるものと推定される。

3.3.5 電着液の温度が工具状態に及ぼす影響

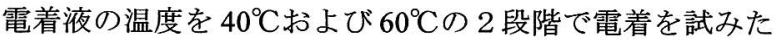




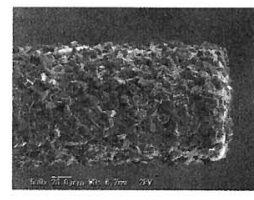

(a) $4 \min$

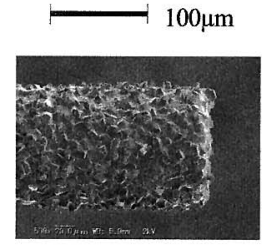

(b) $6 \min$

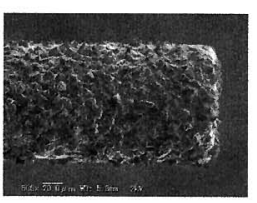

(c) $8 \min$
Grit diameter 8-16um

Fig. 9 Electroplated tools fabricated at different embedding time

が，電着工具の状態にはほとんど違いは生じなかった。 3.3.6 pH が工具状態に及ぼす影響

電着液の $\mathrm{pH}$ を $4.5,5.5$ および 6.5 と変えて電着を試みた が，電着工具の状態にほとんど違いは生じなかった。

3.3.7 埋込み時間が工具状態に及ぼす影響

砥粒径 8〜16 $16 \mathrm{~m}$ の電着工具について，埋込みめっき時間 を $4 \mathrm{~min}, 6 \mathrm{~min}, 8 \mathrm{~min}$ に変化させて工具学製作した. 図9に

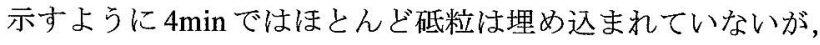
時間の増加とともに深く埋め込まれているようである.

\section{$3.4 \mathrm{Ni}-\mathrm{W}$ 電着工具を用いた加工の本実験}

\section{4 .1 電流密度が工具寿命に及ぼす影響}

電流密度 $0.5,1,2,4 \mathrm{~A} / \mathrm{dm}^{2}$ において電着した工具を用いて 工具寿命試験を行った. 図 10 に示すように, $0.5 \mathrm{~A} / \mathrm{dm}^{2}$ の場 合, $200 \sim 250 \mathrm{~mm}$ とわずかに寿命が短いが，他の電流密度の 工具には目立った差がない。ただし， $4 \mathrm{~A} / \mathrm{dm}^{2}$ は電着層の厚 さが他の工具に比べて $2 \sim 3 \mu \mathrm{m}$ 厚くなったため, 他の工具と 同じ厚さであれば寿命が短くなる可能性がある。

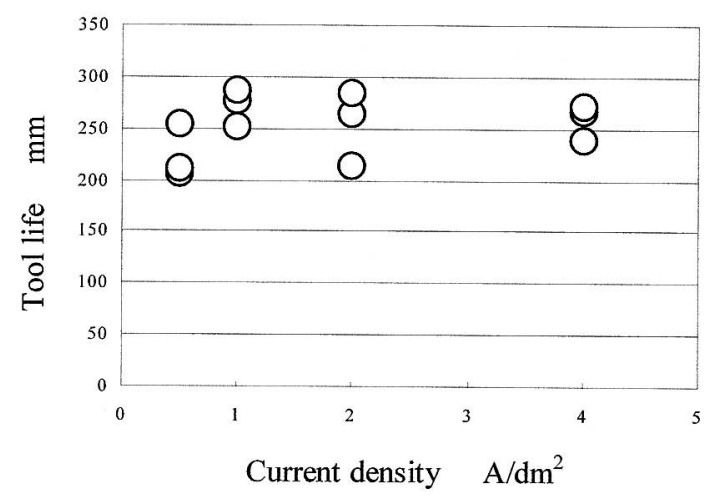

Grit dia. 2-4 $\mu \mathrm{m}$, Grinding speed 30,000 $\mathrm{min}^{-1}$, Feed rate $0.06 \mu \mathrm{m} / \mathrm{rev}$ Fig. 10 Relation between current density and tool life

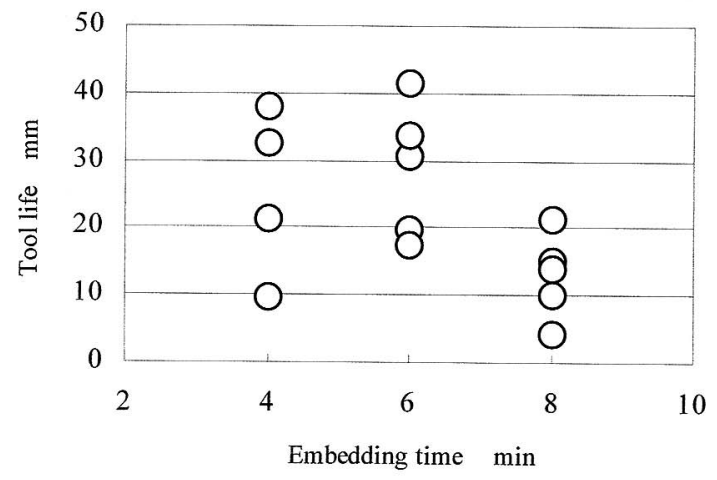

Grit dia. $8-16 \mu \mathrm{m}$, Current density $2 \mathrm{~A} / \mathrm{dm}^{2}$, Elec. time $20 \mathrm{~min}$, Rotational speed $5,000 \mathrm{~min}^{-1}$, Feed $50 \mu \mathrm{m} / \mathrm{min}$

Fig. 11 Effect of embedding time on tool life in Ni-W electroplated tools

\subsection{2 埋込みめつきの時間が工具状態に及ぼす影響}

砥粒径 8〜16 $16 \mathrm{~m}$ の工具については, 図 11 に示すように, 各埋込み時間における工其寿命のばらつきが大きいが，平 均值でとらえると埋込み時間 $6 \mathrm{~min}$ で寿命は最長であると言 えよう。これは, 砥粒の適切な突出し高さが得られ, チッ プポケットの確保と砥粒の十分な保持がバランスした適切

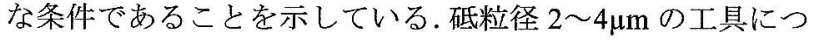
いても埋込みめっきを $0.5 〜 2 \mathrm{~min}$ 行っている.

\subsection{3 研削速度が工具寿命に及ぼす影響}

直径 2 4 $\mu \mathrm{m}$ の砥粒を電流密度 $2 \mathrm{~A} / \mathrm{dm}^{2}$, 電着時閒 $15 \mathrm{~min}$, 埋込み時間 $2 \mathrm{~min}$, 図 1 (b)の擋抖方法で製作した電着工具を, 同一条件下で 3 本ずつ用い, 工具送りを $0.06 \mu \mathrm{m} / \mathrm{rev}$ で一定 として, 工其回転数を $10,000 \sim 50,000 \mathrm{~min}^{-1}$ (研削速度は 3.1 $\sim 15.7 \mathrm{~m} / \mathrm{min}$ ）の範囲で変化させて工具寿命を調べた，その 結果, 各速度での寿命のばらつきは比較的小さく抑えられ， 図 12 に示すように, $9.4 \mathrm{~m} / \mathrm{min}$ で最大值をとることがわかっ た. 従来の砥粒層内に浸漬する方法では工具寿命のばらつ きが大きく最大值と最小值の差が $200 \mathrm{~mm}$ に達することもあ ったが，電着液の擋抖により工具のばらつきを低減させる ことができた，研削速度が高いほど必ずしも寿命が伸びな い理由は明確ではないが, 主軸回転数の上昇によるの振れ の増大，もしくは高速回転による切りくずの噛込の発生の ためと推定される。

\section{4 .4 送り速度が工具寿命に及ぼす影響}

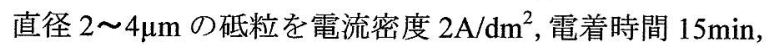
埋込み時間 $2 \mathrm{~min}$, 図 1 (b)の擋拌方法で製作した電着工具を, 同一条件下で 3 本ずつ用い. 工具回転数を $30,000 \mathrm{~min}^{-1}$ （研

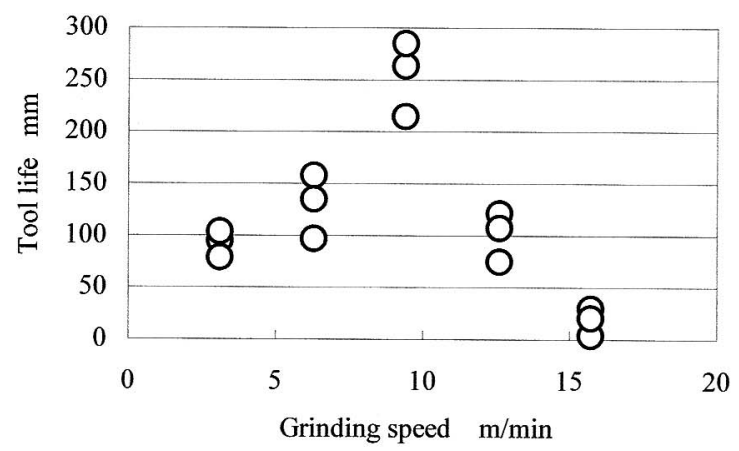

Grit dia. 2-4 $\mu \mathrm{m}$, Current density $2 \mathrm{~A} / \mathrm{dm}^{2}$, Elec. time $15 \mathrm{~min}$, Feed rate $0.06 \mu \mathrm{m} / \mathrm{rev}$

Fig. 12 Relation between grinding speed and tool life

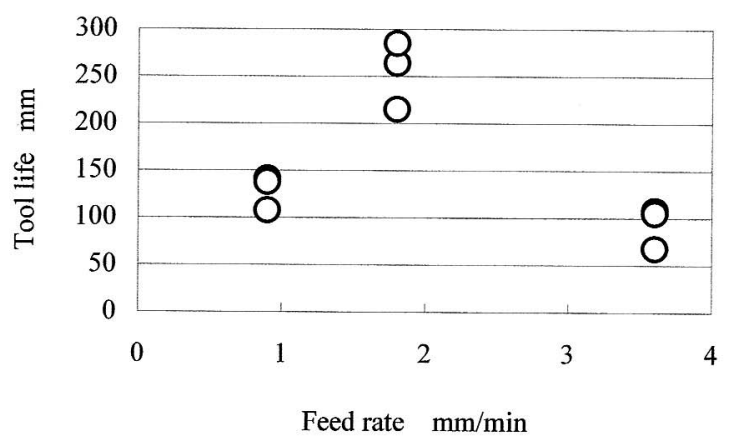

Grit diameter $2-4 \mu \mathrm{m}$, Current density $2 \mathrm{~A} / \mathrm{dm}^{2}$, Elec. time $15 \mathrm{~min}$, Embed. time $2 \mathrm{~min}$

Fig. 13 Relation between feed rate and tool life 


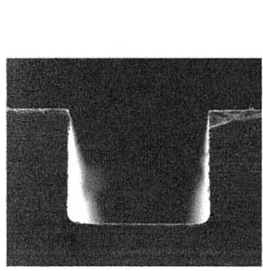

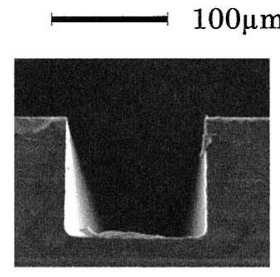

(b) $100 \mathrm{~mm}$

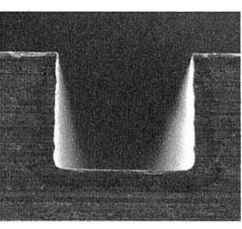

(c) $200 \mathrm{~mm}$ (a) $0 \mathrm{~mm}$

Substrate diameter $100 \mu \mathrm{m}$, Grit diameter $2-4 \mu \mathrm{m}$, Current density $2 \mathrm{~A} / \mathrm{dm}^{2}$, Elec. time $15 \mathrm{~min}$, Embed. time $2 \mathrm{~min}$, Rotational speed $30,000 \mathrm{~min}^{-1}$, Feed $1.8 \mathrm{~mm} / \mathrm{min}$

Fig. 14 Variation of groove entrance with grooving length

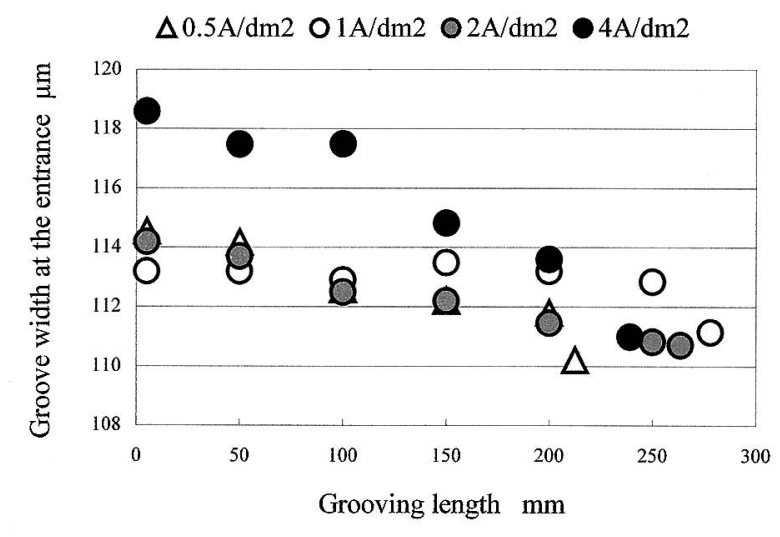

Grinding speed $30,000 \mathrm{~min}^{-1}$, Feed rate $0.06 \mu \mathrm{m} / \mathrm{rev}$

Fig. 15 Variation of groove width with grooving length under different current densities

削速度 $9.4 \mathrm{~m} / \mathrm{min}$ ) で一定として, 工具送りを $0.9 \sim 3.6 \mathrm{~mm} / \mathrm{min}$ $(0.03 \sim 0.12 \mu \mathrm{m} / \mathrm{rev})$ の範囲で変化させて工具寿命を調べた. その結果, 寿命のばらつきは比較的小さく図 13 に示すよう に $1.8 \mathrm{~mm} / \mathrm{min}(0.06 \mu \mathrm{m} / \mathrm{rev})$ で最長となった.このときの砥 粒 1 個当たりの平均切取り厚さは約 $0.5 \mathrm{~nm}$ である. 送りが 小さいときに工具寿命が短いのは，目づまりなどにより砥 粒の脱落が比較的速く起こるためである．これは，溝加工 長さに対する加工溝幅の減少割合からわかる（詳細は後の 報告に譲る)。また，送りが大きいときに工具寿命が短いの は，砥粒の保持強さ以上の研削力が作用するために砥粒が 急速に脱落するためである.これも溝加工長さに対する加 工溝幅の減少割合からわかる.

\subsection{5 加工溝の幅と形状の研削進行に伴う変化}

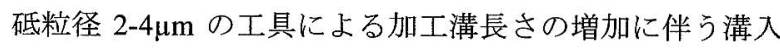
口形状の変化の一例は, 図 14 に示すようになる. 加工溝の 長さが 150 ないし $200 \mathrm{~mm}$ まではチッピングがなく比較的な めらかな輪郭を呈する，ただし，最初は溝入口部に凹凸が 現れることがある.これは, 最初, 最も外側の砥粒が加工 に関与するため砥粒の保持力が不十分な砥粒があると脱落 するためである．このリスクを回避するためには，ごく短 い距離だけ捨て削りをするのが良いと思われる. 図 15 は電 流密度 $0.5,1,2,4 \mathrm{~A} / \mathrm{dm}^{2}$ で製作した工具についての溝加工長 さに対する溝幅の変化を示す. $4 \mathrm{~A} / \mathrm{dm}^{2}$ の工具だけは初期工 具径が大きかったが, 溝加工長さ $0 \sim 200 \mathrm{~mm}$ の範囲で幅減 少割合が約 $0.025 \mu \mathrm{m} / \mathrm{mm}, 0.5$ と $2 \mathrm{~A} / \mathrm{dm}^{2}$ については約 0.013 $\mu \mathrm{m} / \mathrm{mm}, 1 \mathrm{~A} / \mathrm{dm}^{2}$ については $0 \mu \mathrm{m} / \mathrm{mm}$ に近い值となった.

\section{4. 結 論}

$\mathrm{Ni}-\mathrm{W}$ 電着ダイヤモンド工具の製作およびそれを用いた加 工の実験結果および考察から，以下のように結論できる.

(1) Ni めつきおよび Ni-W めっきのビッカース硬さ HV はそ れぞれ 200 と 620 であり, 後者が約 3 倍の值をもつ.

(2) $\mathrm{Ni}-\mathrm{W}$ 電着工具を用いたシリコンへの溝加工から, Ni 電着工具の約 2 倍の寿命を示した.

(3) アンモニア性クエン酸塩浴における Ni-W を用いたダイ ヤモンド電着において, 工具寿命の点から電流密度は $0.5 \sim 2 \mathrm{~mA} / \mathrm{dm}^{2}, \mathrm{pH}$ は 6 程度, および温度は $60^{\circ} \mathrm{C}$ 程度が 最適であることがわかった。

(4) 電着工具表面の砥粒分布を一様にするためには, 砥粒径

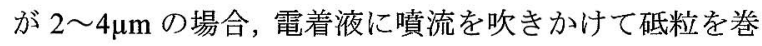
上げ空気流により液の流れを起こすことが有効である. 砥粒沈降速度の速い $5 \sim 10 \mu \mathrm{m}$ および 8〜 16 $\mu \mathrm{m}$ の場合, 台金先端を砥粒層内に沈めて回転させるのが有効であ る.

(5) 砥粒径 2 $4 \mu \mathrm{m}$ の工具について, 工具回転数を 30,000 $\min ^{-1}$ (周速 $9.4 \mathrm{~m} / \mathrm{min}$ ) で一定とし, 工具送りを $0.9 \sim$ $3.6 \mathrm{~mm} / \mathrm{min}$ の範囲で変化させて工具寿命を調べたとこ ろ比較的ばらつきが小さく $1.8 \mathrm{~mm} / \mathrm{min}$ で最長となった.

(6) 砥粒径 2 $4 \mu \mathrm{m}$ の工具について, 工具送りを $0.06 \mu \mathrm{m} / \mathrm{rev}$ で一定とし, 工具周速を 3.1 15.7m/min の範囲で変化 させて工具寿命を調べたところ, 比較的ばらつきが小さ く, $9.4 \mathrm{~m} / \mathrm{min}$ で最長となった.

\section{謝 辞}

本研究の害施にあたり，研究費を援助していただきまし た（財）大澤科学技術振興財団に深く感謝申し上げます。 た, 貴重なご助言をいただきました九州大学大学院工学研 究院福島久哲教授, 中野博昭助教授, 福岡工業大学仙波卓 弥教授，当研究室で電着技術の開発に協力してくれた井上 龍一氏 (現在, 住友電気工業㑣), 奥野佳太郎氏（現在, ヤ マハ発動機(株) ならびに三島光産株式会社に梁く感謝申し 上げます。

また, 本研究における電着工具とそれによる加工溝の観 察, ならびに写真撮影には, 九州大学中央分析センターの 走查電子顕微鏡を用いた.

\section{参 考 文 献}

1) O. Ohnishi, H. Onikura, A. Hata and K. Yamamoto: Fabrication of Micro Flat Drills by Precision Grinding and Drilling into Duralumin and Stainless Steel with Ultrasonic Vibration, JSME Int. J., Series C, 47, 1 (2004) 117.

2) Y. Takeuchi, S. Maeda, K.Sawada and T. Kawai: Creation of Ultraprecision Microgrooves Using Non-Rotational Cutting Tools, Proc. of $2^{\text {nd }}$ euspen Int. Conf. (2001) 636.

3) H. Onikura, B.K. Shil, O. Ohnishi, R. Inoue and T. Semba: Fabrication of Micro Cylindrical Diamond Grinding Tools by Ultrasonic Vibration Grinding for Drilling of Brittle Materials Proc. of the $2^{\text {nd }}$ euspen Int. Conf. (2001) 672.

4) H. Yang, S-W. Kang and R.F. Shyu: The Investigation of Embedding Abrasive Grits onto the Microgrinding Tools by Nickel Electroforming Proc. of $1^{\text {st }}$ euspen Int. Conf. (1999) 392.

5) T. Semba and H. Sato: Development of Electroformed Diamond Tool with Fine Grains Coated by Metal Oxide Film Annals of the CIRP, 49, 1 (2000) 157. 